\title{
Effect of Gastric Inhibitory Polypeptide on Plasma Levels of Chylomicron Triglycerides in Dogs
}

\author{
Taro Wasada, Kay McCorkle, Virginia Harris, Koichi KaWai, \\ Barbara HowARD, and Roger H. UNGER, Veterans Administration \\ Medical Center and University of Texas Health Science Center, Dallas, Texas \\ 75216; National Institutes of Health, Phoenix, Arizona 85016
}

\begin{abstract}
A B S T RACT To determine whether gastric inhibitory polypeptide (GIP) promotes the clearance of chylomicron triglycerides (TG) from the circulation in dogs, chyle collected from donor dogs via a thoracic duct fistula was infused at a rate of $2 \mathrm{ml} / \mathrm{min}$ i.v. into normal recipient dogs during an infusion of either porcine GIP $(1 \mu \mathrm{g} / \mathrm{kg}$ per $\mathrm{h})$ or saline as a control. In the GIP-infused dogs the rise in plasma TG was significantly below that of the control animals [mean peak of $36 \pm 4 \mathrm{mg} / \mathrm{dl} \mathrm{vs}$. $82 \pm 18 \mathrm{mg} / \mathrm{dl}(P<0.05)]$. It is concluded that GIP exerts an effect upon the removal of chylomicron TG from the blood. The results suggest that GIP may play a physiologic role in the disposition of ingested fat.
\end{abstract}

\section{INTRODUCTION}

Eckel et al. (1) recently demonstrated that gastric inhibitory polypeptide (GIP) ${ }^{1}$ stimulates the release and synthesis of lipoprotein lipase by cultured preadipocytes (3T3-L1) in a dose-dependent manner. They suggested that GIP plays a role in removal of postprandial chylomicron triglycerides from the circulation. Their suggestion led us to determine if this effect of GIP can be demonstrated in vivo. To simulate a postprandial condition of fat ingestion, chyle was collected from dogs via a thoracic duct fistula and infused into normal recipient dogs receiving either GIP or a saline solution by intravenous infusion. The changes in the plasma concentration of triglycerides (TG) were compared in the two groups.

\section{METHODS}

Chyle was collected continuously via a surgically implanted thoracic duct catheter from the donor dogs after feeding an

Received for publication 15 May 1981 and in revised form 22 July 1981.

${ }^{1}$ Abbreviations used in this paper: GIP, gastric inhibitory polypeptide; SLI, somatostatin-like immunoreactivity; TG, triglycerides. $800-\mathrm{g}$ fatty meal. The chyle was passed through clean gauze to remove clots. EDTA was then added to the chyle in a final concentration of $\sim 1 \mathrm{mg} / \mathrm{ml}$ to minimize a breakdown of lipoproteins. It was stored overnight at $4^{\circ} \mathrm{C}$ and the next morning the top creamy layer was aspirated and pooled for injection in recipient dogs. The triglyceride concentration of this creamy layer determined in 19 samples obtained from four dogs was $2.3 \pm 0.2 \mathrm{~g} / \mathrm{dl}$.

A group of six intact fasting dogs weighing $23.5-26.0 \mathrm{~kg}$ received an intravenous infusion of purified porcine GIP (kindly provided by Dr. John Brown, The University of British Columbia, and Dr. J. Gardner, National Institutes of Arthritis, Metabolism, and Digestive Diseases) dissolved in $0.1 \%$ bovine serum albumin (BSA) in normal saline at a rate of $1 \mu \mathrm{g} / \mathrm{kg}$ per $\mathrm{h}$ over $2 \mathrm{~h}$. This dose has been reported to raise plasma GIP levels to those observed after a fatty meal $(2,3) .1 \mathrm{~h}$ after the start of GIP infusion the chyle was coinfused at a rate of $2.0 \mathrm{ml} / \mathrm{min}^{2}$ for an additional hour, which was estimated to deliver $\sim 45 \mathrm{mg} / \mathrm{min}$ of triglycerides. This is 1.5 times greater than the estimated rate of triglyceride entry $(30 \mathrm{mg} / \mathrm{min})$ after an intragastric fat load. In a control group of six dogs (24.0$26.0 \mathrm{~kg}$ ), which included two members of the experimental group, normal saline solution without GIP was infused under otherwise identical conditions.

Plasma triglyceride levels were determined by the method of Bucolo and David (4). Insulin, glucagon, and somatostatin-like immunoreactivity (SLI) were measured by modifications of described methods (5-7). Results were analyzed using Student's $t$ test for paired or nonpaired data.

\section{RESULTS}

In the control group (Fig. 1) that received chyle during an infusion of saline, plasma triglyceride levels rose from a mean preinfusion level of $8.0 \pm 0.7 \mathrm{mg} / \mathrm{dl}$ (mean $\pm \mathrm{SE})$ to the peak value of $81.7 \pm 18.0 \mathrm{mg} / \mathrm{dl}(P<0.01)$ at $120 \mathrm{~min}$. After the end of the infusion they declined to base-line levels within $20 \mathrm{~min}$. There were no significant changes in glucose, insulin, glucagon, or SLI. By contrast in the experimental group, which received the chyle infusion during an infusion of GIP, plasma triglyceride levels rose from a mean base line of 9.5 $\pm 1.2 \mathrm{mg} / \mathrm{dl}$ to a mean peak value of only $36.3 \pm 3.7 \mathrm{mg} / \mathrm{dl}$ at $100 \mathrm{~min}(P<0.001)$. Triglycerides were significantly below the control values at all points between 80 to 130 


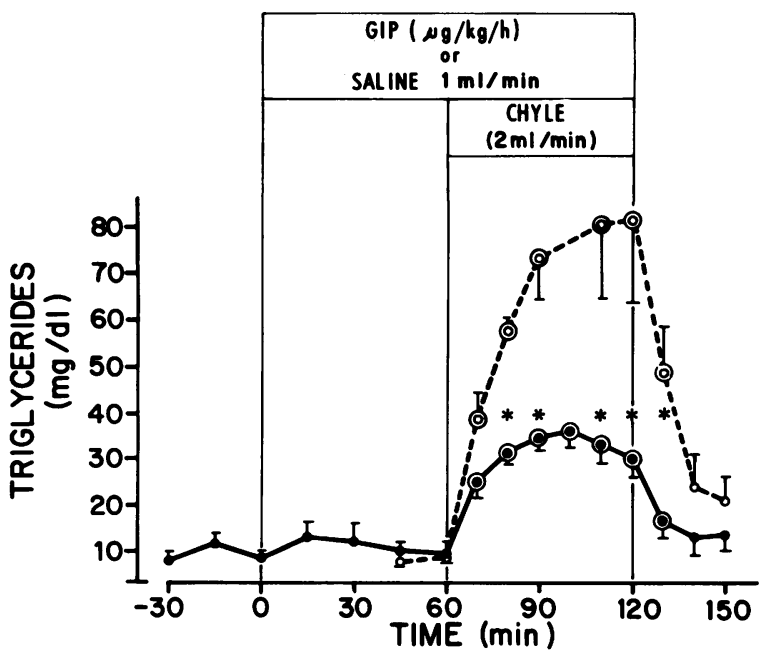

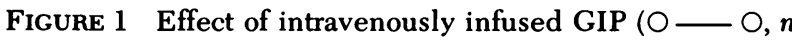
$=6)$ or saline $(\bigcirc---\bigcirc, n=6)$ as a control on plasma levels of TG before and during superinfusion of chylomicrons in normal dogs. $\odot \odot$, Significant differences at $P<0.05$ vs. mean base-line level. *, Significant differences at $P<0.05$ between the two groups.

min $(P<0.02)$. After discontinuation of the chylomicron infusion, triglycerides returned to their preinfusion level within $20 \mathrm{~min}$.

Plasma glucose rose significantly from $75.3 \pm 7.8$ $\mathrm{mg} / \mathrm{dl}$ to a mean peak of $85.0 \pm 4.5 \mathrm{mg} / \mathrm{dl}$ at $80 \mathrm{~min}$ $(P<0.005)$. Plasma glucagon rose significantly from a mean base-line level of $42.2 \pm 3.4 \mathrm{pg} / \mathrm{ml}$ to $73.5 \pm 13.6$ $\mathrm{pg} / \mathrm{ml}(P<0.05)$ during the infusion of GIP alone, and after the start of chylomicron infusion it increased progressively to a peak of $145.2 \pm 57.3 \mathrm{pg} / \mathrm{ml}(P<0.05)$ at the end of the infusion. Plasma insulin rose modestly, but not significantly and SLI did not change.

\section{DISCUSSION}

This study supports the concept of Eckel et al. (1) that GIP stimulates the adipose tissue lipoprotein lipase activity and thereby accelerates the removal of chylomicron triglycerides from the circulation. The pretreatment with GIP followed by chylomicron infusion at a rate approximately three times the estimated physiological rate of postprandial triglyceride entry, resulted in a range of triglyceride levels similar to those observed after a fat meal. (Triglyceride levels after ingestion of $100 \mathrm{ml}$ of corn oil in six normal dogs averaged $35.3 \pm 9.2 \mathrm{mg} / \mathrm{dl}$ at $120 \mathrm{~min}$ and $42.3 \pm 9.5 \mathrm{mg} / \mathrm{dl}$ at 180 min (unpublished data), but it is likely that peak values occur after $3 \mathrm{~h}$.) Because the infusion rate of chyle was identical in all experiments, the findings are consistent with a role for endogenous GIP, which is stimulated by a fat meal $(8,9)$, in the postprandial activation of the adipose tissue LPL, a rate-determining enzyme for the clearance of chylomicrons. Insulin levels were not different, while GIP was again shown to be glucagonotropic, confirming previous studies (10). Although no effects of GIP on peripheral venous SLI levels were observed, GIP in this dose stimulates pancreatic vein SLI levels (10). In addition, the study indicates that chylomicrons do not effect SLI release, anymore than they influence insulin or glucagon release (11).

\section{ACKNOWLEDGMENTS}

We thank the following persons for their expert technical assistance: Loretta Clendenen, Helen Gibson, Mary Lintner, Lovie Peace, and Daniel Sandlin. For secretarial assistance, the authors thank Susan Kennedy.

This work was supported by Veterans Administration Institutional Research Support grant 549-8000-01; National Institutes of Health grant AM-02700-16 and contract N01-AM6-2219; Ciba-Geigy Corp., Summit, N. J., Eli Lilly \& Company, Indianapolis, Ind.; and The Salk Institute-Texas Research Foundation, Houston, Tx.

\section{REFERENCES}

1. Eckel, R. H., W. Y. Fujimoto, and J. D. Brunzell. 1979. Gastric inhibitory polypeptide enhanced lipoprotein lipase activity in cultured preadipocytes. Diabetes. 28: 1141-1142.

2. Dupre, J., S. A. Ross, D. Watson, and J. C. Brown. 1973. Stimulation of insulin secretion by gastric inhibitory polypeptide in man. J. Clin. Endocrinol. Metab. 37: 826-828.

3. Brown, J. C., J. L. Frost, S. Kwauk, S. C. Otte, and C. H. S. McIntosh. 1980. Gastric inhibitory polypeptide (GIP): isolation, structure and basic functions. In Gastrointestinal hormones. G. B. J. Glass, editor. Raven Press, New York. pp. 223.

4. Bucolo, G., and H. David. 1973. Quantitative determination of serum triglyceride by use of enzymes. Clin. Chem. 19: 475-482.

5. Yalow, R. S., and S. A. Berson. 1960. Immunoassay of endogenous plasma insulin in man. J. Clin. Invest. 39: 1157-1175.

6. Harris, V., G. R. Faloona, and R. H. Unger. 1979. Glucagon. In Methods of Hormone Radioimmunoassay. B. M. Jaffe and H. R. Behrman, editors. Academic Press, New York. pp. 643-656.

7. Harris, V., J. M. Conlon, C. B. Srikant, K. McCorkle, V. Schusdziarra, E. Ipp, and R. H. Unger. 1978. Measurements of somatostatin-like immunoreactivity in plasma. Clin. Chim. Acta. 87: 275-283.

8. Falko, J. M., S. E. Crockett, S. Cataland, and E. L. Mazzaferri. 1975. Gastric inhibitory polypeptide (GIP) is stimulated by fat ingestion in man.J. Clin. Endocrinol. Metab. 41: 260-265.

9. Pederson, R. A., H. E. Schubert, and J. C. Brown. 1975. Gastric inhibitory polypeptide. Its physiologic release and insulinotropic action in the dog. Diabetes. 24: 10501056.

10. Rouiller, D., V. Schusdziarra, V. Harris, and R. H. Unger. 1980. Release of pancreatic and gastric somatostatin-like immunoreactivity in response to the octapeptide of cholecystokinin, secretin, gastric inhibitory polypeptide and gastrin-17 in dogs. Endocrinology. 107: 524-529.

11. Böttger, I., R. Dobbs, G. R. Faloona, and R. H. Unger. 1973. The effect of triglyceride absorption upon glucagon, insulin and gut glucagon-like immunoreactivity. J. Clin. Invest. 52: 2532-2541. 